\title{
ANALISIS YURIDIS BENTUK PERJANJIAN ANTARA PERUSAHAAN ASURANSI KERUGIAN DENGAN PERUSAHAAN LOSS ADJUSTER
}

\author{
Ralang Hartati \\ Fakultas Hukum Universitas Tama Jagakarsa Jakarta
}

\begin{abstract}
In practice, insurance companies, before paying a claim to the insured, always use the services of a loss adjuster firm when the field assessment of the loss is considered complicated and difficult and the amount of the claim is relatively significant. This paper is to briefly describe the format of the existing contracts or agreements between loss adjuster firms and insurance companies.
\end{abstract}

Keyword : Loss adjuster

Abstrak

Dalam prakteknya, perusahaan asuransi, sebelum membayar klaim tertanggung, selalu menggunakan jasa perusahaan Loss Adjuster, ketika penilaian lapangan kerugian dianggap rumit dan sulit, dan nilai klaim cukup besar. Tulisan ini dimaksudkan untuk menggambarkan secara singkat tentang bagaimana bentuk perjanjian yang ada antara perusahaan adjuster asuransi kerugian dengan perusahaan asuransi.

Kata kunci : Loss Adjuster

\section{Pendahuluan}

Dalam hal terjadinya klaim dan guna menghindari pembayaran klaim yang melebihi pembayaran yang seharusnya oleh perusahaan asuransi kerugian, terlebih dahulu dilakukan proses penilaian kerugian. Penilaian ini penting dilakukan agar perusahaan asuransi dapat membayar klaimnya secara wajar dan cepat. Ada dua tindakan penilaian kerugian yang dilakukan oleh pihak asuransi, yaitu penilaian polis dan penilaian klaim. Apabila keabsahan polis terkonfirmasi, selanjutnya akan dilakukan penelitian klaim berupa penelitian lapangan. Penelitian lapangan ini dilakukan untuk mengetahui : penyebab terjadinya kerugian, tempat terjadinya, jumlah kerugian yang dialami (taksiran), dan usaha yang dilakukan tertanggungg untuk memperkecil kerugian pada saat terjadinya. 
Dalam asuransi kerugian, penilai kerugian ini dikenal dengan nama adjuster atau loss adjuster, yang merupakan salah satu penunjang perusahaan asuransi. Adjuster inilah yang akan melakukan penelitian lapangan untuk mengadakan penyidikan. Penilai ini dapat berasal dari staff penilai dari asuransi tersebut atau dapat berasal dari penilai publik yang independen. Biasanya agen dapat berfungsi sebagai penilai kerugian dalam hal klaimnya sederhana dan kerugian yang dideritapun kecil. Kebanyakan asuransi memperkerjakan penilai tetap (yang digaji tetap) mewakili perusahaan asuransi, yang dalam istilah asuransi dikenal dengan nama "surveyor". Tetapi apabila klaim itu rumit sehingga memakan waktu yang cukup lama maka penilaian atas kerugian oleh perusahaan asuransi diserahkan kepada biro penilai yang bersifat independen, yang sering dikenal dengan sebutan "loss adjuster".

Dalam Undang - undang No.2 tahun 1992 tentang Usaha Perasuransian, pada Pasal 3 butir $b$, disebutkan bahwa usaha penunjang perusahaan asuransi terdiri dari:

1. Usaha pialang asuransi yang memberikan jasa keperantaraan dalam penutupan asuransi dan penanganan penyelesaiaan ganti rugi asuransi, dengan bertindak untuk kepentingan tertanggung;

2. Usaha pialang reasuransi yang meberikan jasa keperantaraan dalam penempatan reasuransi dan penanganan penyelesaiaan ganti rugi reasuransi dengan bertindak untuk kepentingan - kepentingan perusahaan reasuransi.

3. Usaha penilaian kerugian asuransi yang memberikan jasa penilaian terhadap kerugian pada objek asuransi yang dipertanggungkan;

4. Usaha konsultan aktuaria yang memberikan jasa konsultan aktuaria;

5. Usaha agen asuransi yang memberikan jasa keperantaraan dalam rangka pemasaran jasa asuransi untuk dan atas nama perusahaan asuransi atau penanggung.

Dari ketentuan pasal di atas, yang merupakan perusahaan Loss Adjuster adalah butir 3, yaitu usaha penilai kerugian asuransi. Dengan diserahkannya penilaian kerugian kepada biro penilai yang bukan merupakan bagian dari 
perusahaan asuransi, berarti disini dapat dilihat bahwa antara perusahaan asuransi kerugian dan biro penilai tersebut telah terjalin suatu kerjasama. Dan dalam tulisan ini, penulis akan membahas kerjasama yang dilakukan oleh pihak asuransi kerugian dengan perusahaan loss adjuster dengan melihat bagaimana bentuk perjanjian antara perusahaan asuransi kerugian dengan perusahaan loss adjuster tersebut.

\section{Pembahasan}

\section{Pengertian Asuransi atau Pertanggungan}

Pengertian asuransi diatur dalam Pasal 246 KUHD, yang berbunyi : "Asuransi atau pertanggungan adalah suatu perjanjian, dengan mana seorang penanggung mengikatkan diri kepada seorang tertanggung dengan menerima suatu premi, untuk memberikan penggantian kepadanya karena suatu kerugian, kerusakana atau kehilangan keuntungan yang diharapkan yang mungkin akan dideritanya karena suatu peristiwa tertentu ". 1

Dalam UU.No2 Tahun 1992 Tentang Usaha Perasuransian, pengertian asuransi di atur dalam Pasal 1 butir (1) yang berbunyi :

"Asuransi atau pertanggungan adalah perjanjian antara dua pihak atau lebih, dengan mana pihak penanggung mengikatkan diri pada pihak tertangung dengan menerima premi asuransi, untuk memberikan penggantian kepada tertanggung karena kerugian atau kerusakan atau kehilangan keuntungan yang diharapkan, atau tanggung jawab hokum kepada pihak ketiga yang timbul dari suatu peristiwa yang tidak pasti, atau untuk memberikan suatu pembayaran yang didasarkan atas meninggal atau hidupnya seseorang yang dipertanggungkan."2

Kalau dibandingkan antara dua pengertian di atas yaitu pengertian asuransi menurut pasal 246 KUHD dan Pasal 1 butir (1) UU NO.2 Tahun 1992 maka pengertian asuransi menurut Pasal 1 butir (1) sudah mengalami perluasan diantaranya dalam Pasal 246 KUHD tidak disinggung pengertian asuransi jiwa, walaupun ada beberapa pasal dalam KUHD mengatur materi asuransi jiwa, tetapi dalam UU No.2 tahun 1992 sudah mencakup pengertian asuransi jiwa, asuransi kerugian bahkan bentuk asuransi tanggung jawab, walaupun demikian, masih

\footnotetext{
${ }^{1}$ Republik Indonesia, Kitab Undang - Undang Hukum Dagang dan Undang - Undang Kepailitan, (Jakarta, Pradnya Paramita, 1983)..

${ }^{2}$ Republik Indonesia, UU No,2 Tahun 1992 Tentang Usaha Perasuransian.
} 
terdapat kekurangan, di mana pengertian asuransi wajib / sosial belum terdapat di dalam pengertian asuransi menurut UU No.2 Tahun 1992 tersebut.

Dalam perjanjian asuransi pihak tertanggung mengalihkan resikonya kepada pihak penanggung (perusahaan asuransi) terhadap kerugian - kerugian yang diderita tertanggung akibat perbuatan yang tidak pasti. Dengan demikian persyaratan untuk mendapatkan ganti rugi di gantungkan kepada peristiwa yang belum pasti terjadinya.

\section{Pengertian Loss Adjuster}

Berdasarkan Undang - undang No.2 Tahun 1992 dan Peraturan Pemerintah No.39 tahun 2008 tentang Penyelenggaraan Usaha Perasuransian, disebut bahwa salah satu penunjang perusahaan asuransi adalah Penilai Kerugian Asuransi (loss adjuster) yang memberikan jasa penilaian terhadap kerugian pada obyek asuransi yang dipertanggungkan.

Dalam literature, istilah loss adjuster sama dengan penilaian kerugian, seperti yang disebutkan dalam Pasal 1 butir 11 Undang - undang No.2 tahun 1992 tentang Usaha Perasuransian.

Menurut Purwosucipto Loss Adjuster adalah : ${ }^{3}$

"Suatu perusahaan yang bersedia untuk menghitung jumlah kerugian yang benar - benar telah diderita oleh tertenggung". Loss Adjuster haruslah benar-benar orang yang ahli yang bisa menaksir secara tepat nilai atau harga barang yang musnah pada saat terjadi evenemen / kerugian.

Menurut Robertus Ismono.

Loss adjuster adalah suatu profesi dalam industri asuransi yang memberikan jasa berupa pemeriksaan dan atau penilaian atas klain ganti asuransi yang diajukan oleh tertanggung penanggung berdasarkan persyaratan - persyaratan yang terdapat di dalam polis". 4

Menurut Burkinshaw Loss Adjuster adalah :5

"Loss Adjuster are intermediaries of quite a different type. They are independent professionals whose service are available to any insurer or

\footnotetext{
${ }^{3}$ HMN Purwosucipto, Pengertian Pokok Hukum Dagang Indonesia Seri Hukum Pertanggungan, (Bandung, : Alumni, 1996) hal, 183

${ }^{4}$ Robertus Ismono, seorang Adjuster dari PT Dharma Nilaitama di Jakarta, wawancara, $\operatorname{tgl} 12$ Apri

${ }^{5}$ Burkinstravo, M J, Study Cours Introduction Insurance, (Institute Of New Zealand, 1996), hal 2
} 
individual who may to have a claim investigated or adjusted". The may, for example, he engaged by an insurance company to advise it is to wheather they are any suspicious circumstances soufounding a fire, or to investigate a motor accident, resporting an the cause, the damage, and the quotation for repairs. A number of insurance companies also emplioy staff assessor an a salary basic. Despite the fact that they may be salaried employees they still maintain they traditional role as impartial arbiters"

(Terjemahan : Loss Adjuster atau juru taksir adalah perantara untuk penyelesaiaan ganti kerugian. Juru taksir adalah orang yang melaksanakan tugas secara professional dan tidak mihak (independen), guna menyelesaikan klaim asuransi atau penaksiran ganti rugi, sebagai contoh, perusahaan asuransi menggunakan adjuster untuk memberikan penjelasan mengenai kasus - kasus kebakaran, kecelakaan kendarmeaan, dan penetapan penilaian untuk perbaikan.

Dalam Undang - undang No.2 tahun 1992 tentang Usaha Perasuransian, ada beberapa pasal yang mengatur perusahaan penilaian kerugian yaitu :

- Pasal 1 butir 11 yang menyebutkan bahwa perusahaan penilai kerugian ini dalam prakteknya adalah perusahaan Adjuster asuransi Indonesia, yang memberikan jasanya pada perusahaan asuransi kerugian.

- Selanjutnya Pasal 5 butir c, menyebutkan bahwa perusahaan penilai kerugian asuransi hanya dapat menyelenggarakan usaha jasa penilaian kerugian atas kehilangan atau kerusakan yang terjadi pada obyek asuransi kerugian. Pasal ini mengatur batasan kerja perusahaan Adjuster.

Keberadaan perusahaan Adjuster asuransi Indonesia, sudah diakui dalam bisnis perusahaan asuransi kerugian. Artinya perusahaan asuransi kerugian akan selalu membutuhkan perusahaan adjuster asuransi dalam kasus yang dianggap rumit dan sulit sebagai rekan / mitra kerjanya untuk menilai kerugian yang terjadi. Perusahaan adjuster asuransi Indonesia pada umumnya bergerak dalam kegiatan avarage adjuster dan loss adjuster. Tetapi dalam perkembangannya sekarang sedah bertambah 2 (dua) kegiatan lain, yaitu : car assessor dan energy adjuster, walaupun dalam prakteknya kedua kegiatan tersebut jarang sekali dilakukan. 
Perusahaan penilai kerugian / adjuster asuransi berada di bawah naungan Departemen Keuangan. Perusahaan adjuster ini tunduk pada peraturan Undangundang No.2 tahun 1992 tentang Usaha Perasuransian yo. Peraturan Pemerintah No.73 tahun 1992 tentang Penyelenggaraan Usaha Perasuransian yo. Keputusan Menteri No. 226/KMK.017/1993 tentang Perizinan dan Penyelenggaaan Kegiatan Usaha Perusahaan Penunjang Usaha Asuransi.

Untuk mendirikan perusahaan adjuster harus dipenuhi ketentuan Pasal 1 ayat (1) dan Pasal 3 ayat (1) Keputusan Menteri Keuangan Republik Indonesia No.226/KMK.017/1993 tentang Perizinan dan Kegiatan Usaha Perusahaan Penunjang Usaha Asuransi. Pasal 1 ayat (1) tersebut berbunyi : "Untuk mendapatkan persetujuan prinsip bagi perusahaan pialang asuransi, perusahaan pialang reasuransi dan perusahaan penilai kerugian, permohonan dapat diajukan secara tertulis kepada menteri dengan melampirkan bukti persyaratan sebagaimana dimaksud dalam Pasal 9 ayat (3) Peraturan Pemerintah No.73 tahun 1992 tentang Penyelenggaraan Usaha Perasuransian”.

Dalam Pasal 9 ayat (3) Peraturan Pemerintah No.73 tahun 1992 tentang Penyelenggaraan Usaha Perasuransian ditentukan "permohonan persetujuan prinsip bagi perusahaan perasuransian " sebagaimana dimaksud dalam ayat (1) huruf a, diajukan kepada menteri dengan melampirkan :

a. Anggaran dasar perusahaan yang dibuat dihadapan notaries;

b. Rencana susunan organisasi perusahaan;

c. Rencana pengguanan tenaga ahli oelh perusahaan;

d. Rencana kerja perusahaan dalam garis besar;

e. Rencana perjanjian kerjasama dengan pihak asing;

f. Bukti penempatan deposito.

Selanjutnya dalam Pasal 3 ayat (1) Keputusan Menteri Keuangan Republik Indonesia No.226/KMK.017/1993 tentang Perizinan dan Kegiatan Usaha Perusahaan Penunjang Usaha Asuransi, disebutkan : "Perusahaan pialang asuransi atau perusahaan pialang reasuransi atau perusahaan penilai kerugian asuransi dapat mengajukan permohonan izin usaha secara tertulis kepada menteri selambat - lambatnya 1 (satu) tahun sejak tanggal persetujuan prinsip 
sebagaimana dimaksud dalam Pasal 9 ayat (4) Peraturan Pemerintah No.73 tahun 1992 tentang Penyelenggaraan Usaha Perasuransian”.

Adapun Pasal 9 ayat (4) Peraturan Pemerintah No.73 tahun 1992 tentang Penyelenggaraan Usaha Perasuransian, menyebutkan bahwa : "Permohonan prinsip sebagaimana dimaksud dalam ayat (1) huruf a berlaku untuk jangka waktu 1 (satu) tahun “

Dengan demikian bagi perusahaan adjuster asuransi yang dalam 1 (satu) tahun setelah jangka waktu yang ditetapkan tidak mengajukan permohonan tertulis, diharuskan untuk memperbaharui kembali permohonan persetujuan prinsip.

\section{Perjanjian pada umumnya dan perjanjian asuransi}

Secara garis besar pengertian perjanjian dapat dibedakan menjadi 2, yaitu perjanjian dalam arti luas dan perjanjian dalam arti sempit. Perjanjian dalam arti luas adalah setiap perjanjian yang menimbulkan akibat hukum sebagaimana yang telah dikehendaki oleh para pihak. Bila kita telaah dari kata " dikehendaki oleh para pihak" maka dapat dikatakan bahwa perjanjian ada karena adanya kesepakatan atau persetujuan dari para pihak untuk mengikatkan diri satu dengan yang lainnya. Jadi dapat ditarik kesimpulan bahwa perjanjian menimbulkan atau melahirkan perikatan.

Perikatan adalah hubungan hukum antara dua atau lebih orang (pihak) dalam bidang / lapanagan harta kekayaan, yang melahirkan kewajiban pada salah satu pihak dalam hubungan hukum tersebut. ${ }^{6}$ Dan menurut Pasal 1233 KUHPerdata, hubungan hukum dalam perikatan dapat lahir karena kehendak para pihak, sebagai akibat dari persetujuan yang dicapai oleh para pihak, dan sebagai akibat perintah peraturan perundang - undangan. Dengan demikian hubungan hukum dapat lahir sebagai akibat perbuatan hokum yang disengaja atau pun tidak, serta dari suatu peristiwa hukum atau bahkan dari suatu keadaan

\footnotetext{
${ }^{6}$ Kartini Mulyadi dan Gunawan Wijaya, Perikatan Pada Umumnya, (Jakarta: Raja Grafindo, 2004), Hal, 17.
} 
hukum. Dan dari hubungan hukum tersebut lahir kewajiban yang harus dipenuhi oleh salah satu pihak.

Berdasarkan Pasal 1234 KUHPerdata, bentuk kewajiban tersebut dapat berupa memberikan sesuatu, berbuat sesuatu dan tidak berbuat sesuatu, yang disebut dengan prestasi. Dan prestasi untuk melaksanakan kewajiban tersebut di atas memiliki dua unsur penting. ${ }^{7}$ Pertama, berhubungan dengan persoalan tanggung jawab hukum atas pelaksanaan prestasi tersebut oleh pihak yang berkewajiban (schuld), dan Kedua, berkaitan dengan pertanggungjawaban pemenuhan kewajiban dan harta kekayaan pihak yang berkewajiban tersebut.

Bagi perikatan yang lahir dari perjanjian, kewajiban atau prestasi yang disepakati oleh para pihak yang membuat perjanjian jelas adalah sesuatu yang dikehendaki oleh para pihak, sehingga dapat dikatakan bahwadalam perikatan jenis ini, kewajiban atau prestasi yang lahir dari perikatan ini adalah prestasi yang seyogyanya dapat dilaksanakan. Walaupun demikian tidak tertutup kemungkinan bahwa adakalanya dengan berjalannya waktu, kemampuan pihak yang berkewajiban untuk melaksanakan prestasinya tersebut (debitor) menjadi mundur sedemikian rupa sehingga pada akhirnya perikatan tersebut tidak dapat dilaksanakan.

Sehubungan dengan kemampuan untuk melaksanakan prestasi tersebut, dikenal adanya dua macam kemampuan, yaitu: ${ }^{8}$

- Kemampuan objektif;

- Kemampuan subjektif

Yang dimaksud dengan kemampuan objektif adalah kemampuan untuk melaksanakan kewajiban atas prestasi tanpa memperhatikan pihak yang melaksanakan kewajiban atau prestasi tersebut. Kemampuan objektif ini dibedakan dari kemampuan subjektif, yang melekat pada diri individu yang berkewajiban untuk melaksanakan suatu prestasi tertentu (debitor).

Ditinjau dari sifat prestasi yang harus dilakukan, secara teoritis dikenal dua macam prestasi, yaitu: ${ }^{9}$ 
- prestasi yang hanya dapat dipenuhi atau dilaksanakan oleh debitor sendiri, dan

- prestasi yang pemenuhannya dapat dilakukan tanpa kehadiran debitor atau pretasi yang tidak perlu dilaksanakan sendiri oleh debitor sendiri.

Prestasi yang pertama bersifat spesifik, dan pada umumnya merupakan kewajiban atau prestasi yang lahir dari perikatan untuk melaksanakan sesuatu, yang keberadaan dan pelaksanaannya semata - mata digantungkan pada keahlian diri pribadi debitur. Misalnya perikatan yang lahir dari kesepakatan untuk mengadakan penilaian atas klaim asuransi yang nilainya besar dan rumit. Disini perikatan tersebut karena keahlian dari subjek hokum yang merupakan debitur dalam perikatan tersebut.

Sedangkan jenis prestasi kedua, meskipun keberadaannya bergantung pada keberadaan debitur tertentu, namun demikian pelaksanaannya dapat dilakukan tanpa kehadiran atau tanpa bantuan debitur sendiri. Prestasi ini akan melahirkan hubungan hukum baru antara pihak ketiga dengan debitur yang tidak melaksanakan sendiri kewajibannya. Biasanya prestasi kedua ini sering terjadi pada perikatan untuk memberikan sesuatu dan untuk tidak berbuat sesuatu. Perikatan jenis prestasi kedua ini, dapat dilakukan melalui perjanjian pemberian kuasa, yang merupakan salah satu jenis perjanjian bernama.

Pengertian perjanjian pemberian kuasa menurut Pasal 1792 KUHPerdata adalah suatu perjanjian dengan mana seorang memberikan kuasanya kepada seorang lain, yang menerimanya, untuk atas namanya menyelenggarakan suatu urusan. Yang dimaksud dengan menyelenggarakan suatu urusan adalah melakukan suatu perbuatan hukum, yaitu tindakan subjek hukum yang dapat menimbulkan suatu akibat hukum yang dikehendaki oleh pelaku. Si juru kuasa melakukan perbuatan hukum tersebut atas nama / mewakili pemberi kuasa, artinya bahwa apa yang dilakukan oleh si kuasa adalah atas tanggungan si pemberi kuasa dan segala hak dan kewajiban yang timbul dari perbuatan yang dilakukan sikuasa menjadi hak dan kewajiban orang yang memberi kuasa.

\footnotetext{
${ }^{9}$ Ahmadi Miru, Hukum Kontrak, Perancaangan Kontrak, (Jakarta : Rajawali Press, 2007), hal 68
} 
Pemberian kuasa menerbitkan perwakilan, yaitu adanya seorang yang mewakili orang lain untuk melakukan suatu perbuatan hukum. ${ }^{10}$

Dengan demikian dapat disimpulkan perwakilan ada yang lahir karena undang - undang, dan ada pula yang lahir karena perjanjian. Menurut Pasal 1793 KUHPerdata, pemberian kuasa ini dapat dilakukan dengan cara :

1. diberikan dan diterima melalui :

- $\quad$ suatu akta umum

- $\quad$ suatu tulisan dibawah tangan

- sepucuk surat

- secara lisan

2. dilakukan secara diam-diam yang disimpulkan dari pelaksanaan kuasa oleh penerima kuasa.

Ini memperlihatkan bahwa pemberian kuasa bebas dari suatu bentuk dan cara (formalitas), artinya pemberian kuasa itu adalah suatu perjanjian konsensuil, yaitu perjanjian yang lahir karena tercapainya kesepakatan para pihak.

Menurut Pasal 1794 KUHPerdata, jenis pemberian kuasa berdasarkan sifatnya dibedakan menjadi 2 (dua) yaitu :

a. Pemberian kuasa yang terjadi dengan Cuma-Cuma

b. Pemberian kuasa yang terjadi dengan upah (harus diperjanjikan). Pemberian upah disini dapat dilakukan dengan cara :

- ditentukan secara tegas dalam perjanjian (penentuan jumlahnya dinyatakan secara tegas dan jelas), atau

- tidak ditentukan secara tegas dalam perjanjian (disini berdasarkan Pasal 411 KUHPerdata sikuasa tidak meminta upah melebihi yang telah ditentukan pasal tersebut).

Saat ini ketentuan Pasal 1794 KUHPerdata dalam hal pemberian kuasa secara cuma - cuma sudah ditinggalkan oleh kebiasaan yang bersifat umum.

Pemberian upah dimaksudkan sebagai imbalan atas urusan yang telah dilakukan oleh penerima kuasa.

\footnotetext{
${ }^{10}$ Handri Rahardjo, Hukum Perjanjian di Indonesia, (Yogjakarta, Pustaka Yustisia, 2009), hal 177
} 


\section{Bentuk Perjanjian antara Perusahaan Asuransi Kerugian dengan Perusahaan Loss Adjuster.}

Seorang loss adjuster dalam melaksanakan tugasnya di lapangan harus mengacu pada Kode Etik yang dituangkan dalam Pedoman Kerja Adjuster Asuransi Indonesia, yang terdiri dari :

a. Penugasan;

b. Pengawasan;

c. Laporan awal;

d. Permintaan dokumen;

e. Penunjukkan tenaga ahli;

f. Laporan akhir;

g. Laporan interim

Dalam prakteknya seorang loss adjuster dari perusahaan loss adjuster, melaksanakan tugasnya untuk menilai kerugian harus mendapat penugasan terlebih dahulu dari perusahaan asuransi kerugian. Penugasan diberikan oleh perusahaan asuransi kerugian biasanya didahului dengan pembicaraan secara lisan dengan menghubungi perusahaan loss adjuster melalui telepon, atau langsung mengirimkan surat penunjukkan / surat penugasan melalui faksimile atau melalui pos.

Penugasan melalui telepon bagi para loss adjuster sudah merupakan awal perjanjian yang mengikat, karena mereka percaya akan niat baik dari perusahaan asuransi yang menunjuk atau yang memberi tugas pada perusahaannya. Surat penunjukkan yang diberikan oleh perusahaan asuransi kerugian kepada perusahaan loss adjuster mempunyai kekuatan yang mengikat dari aspek pembayaran upah / fee.

Contoh isi Surat Penunjukan dari Perusahaan Asuransi Kerugian kepada Perusahaan Adjuster / Loss Adjuster:

1. Dari perusahaan asuransi kerugian PT Asuransi Umum Bumiputeramuda kepada perusahaan Loss Adjuster PT.Dharma Nilaitama tetanggal 24 April 2011 yang berisikan penunjukan PT 
Dharma Nilaitama sebagai penilai kerugian dari PT Asuransi Umum Bumiputeramuda untuk melakukan Survey / Klaim Fire Standart yang akan menilai berapa besar kerugian yang benar - benar diderita oleh kliennya di lapangan atas nama Tetanggung Zulkifli QQ N.R, No. polis 0101.46.2011.03.0004 \& Ends.0101.46.201103. .0004-1.

2. Dari Perusahaan PT Asuransi Takaful Umum kepada Perusahaan Loss Adjuster PT Dharma Nilaitama yang menunjuk PT Dharma Nilaitama untuk melakukan Survey dan Investigasi untuk klaim atas Perluasan Jaminan atas nama PT INDO PLANTANATIONS, No. Polis : 1.901.10.101.000018. Dol 29/10/2010

Dari kedua isi surat penunjukkan atau surat penugasan di atas, dapat dilihat bahwa pihak perusahaan asuransi kerugian mengirimkan surat penunjukkan kepada perusahaan loss adjuster untuk melakukan penilaian terhadap kerugian yang diderita oleh tertanggung di lapangan, dan dalam melaksanakan tugasnya pihak adjuster mengacu kepada Kode Etik yang sudah ada.

Perjanjian antara perusahaan asuransi kerugian dengan loss adjuster seringkali diawali dengan telepon yang dilanjutkan dengan mengirimkan facsimile.

Apabila diperhatikan isi surat penunjukkan, perjanjian yang terjadi antara perusahaan asuransi kerugian dengan peusahaan loss adjuster, yang dituangkan dalam surat penunjukkan atau surat perintah kerja adalah perjanjian yang diatur dalam Pasal 1601 b KUHPerdata.

Dalam Pasal 1601. KUHPerdata disebutkan bahwa: "Selainnya persetujuanpersetujuan untuk melakukan sementara jasa - jasa yang diatur oleh ketentuan ketentuan yang khusus untuk itu dan oleh syarat-syarat yang diperjanjikan'. Dan jika itu tidak ada oleh syarat - syarat yang diperjanjikan, oleh kebiasaan. Maka adalah dua macam persetujuan dengan mana pihak yang satu mengikatkan dirinya untuk melakukan pekerjaan bagi pihak yang lainnya dengan menerima upah : persetujuan perburuhan dan pemborongan pekerjaan”. 
Dari isi pasal di atas dikaitkan dengan surat penunjukkan atau surat perintah kerja dari perusahaan asuransi kerugian kepada loss adjuster dapat dikatakan bahwa isi surat penunjukkan / surat perintah kerja tersebut memenuhi ketentuan Pasal 1601 KUHPerdata, karena di dalamnya berisikan perintah untuk melaksanakan tugas yaitu menjadi adjuster untuk memberikan penilaian kerugian. Dalam surat penunjukkan tersebut tidak dengan tegas ditentukan perjanjian apa yang dimaksud, tetapi dari surat penunjukkan atau surat perintah kerja itu dapat dimasukkan kedalam perjanjian bersama yang diatur dalam KUHPerdata yang disebut dengan persetujuan - persetujuan untuk melakukan pekerjaan.

Selanjutnya dalam Pasal 1601 b, disebutkan :

"pemborongan pekerjaan adalah persetujuan dengan mana pihak yang satu, pemborong, mengikatkan diri untuk menyelenggarakan suatu pekerjaan bagi pihak yang lain, pihak yang memborongkan, dengan menerima suatu harga yang ditentukan".

Selanjutnya setelah menerima surat penunjukkan atau surat perintah kerja, maka loss adjuster akan melaksanakan tugasnya mengadakan penilaian kerugian di lapangan dengan mendapatkan imbalan upah / fee yang ditentukan sesuai dengan perjanjian. Dalam praktek mengenai upah / fee loss adjuster dari setiap perusahaan loss adjuster tidak sama. Masing - masing perusahaan loss adjuster berbeda - beda sesuai dengan kerugian yang timbul dan ini merupakan rahasia dari perusahaan loss adjuster yang hanya boleh diketahui oleh perusahaan asuransi kerugian yang menunjuknya. ${ }^{11}$

Dalam Pedoman Kerja loss adjuster ditentukan bahwa setelah loss adjuster menerima surat penunjukkan atau surat perintah kerja, loss adjuster akan melaksanakan tugasnya sesuai dengan pedoman kerja yang telah disepakati.

Dalam hal ini ditentukan bahwa loss adjuster setelah memeriksa lokasi kejadian diharuskan untuk membuat laporan awal tentang sebab-sebab kejadian selanjutnya bila telah selesai pemeriksaan, memberikan laporan akhir.

\footnotetext{
${ }^{11}$ Robertus Ismono, seorang Adjuster dari PT Dharma Nilaitama di Jakarta, wawancara, tgl 12 April 2012
} 
Sehubungan dengan tugas tersebut bila dilihat dari KUHPerdata, hal ini memenuhi isi Pasal 1604 KUHPerdata.

Dalam Pasal 1604 KUHPerdata disebutkan bahwa :

"dalam hal pemborongan pekerjaan dapat ditetapkan dalam persetujuan bahwa si pemborong hanya akan melakukan pekerjaan saja atau bahwa ia akan memberikan bahannya".

Tugas loss adjuster yaitu membuat laporan dari laporan awal sampai pada pembuatan laporan akhir, yang nantinya akan diberikan kepada perusahaan asuransi kerugian, dalam konteks ini tugas loss adjuster memenuhi isi Pasal 1604 KUHPerdata, karena loss adjuster memberikan bahannya kepada perusahaan asuransi kerugian. Pekerjaan loss adjuster dilakukan secara bertahap dalam arti memenuhi Pasal 1608 KUHPerdata.

Pasal 1608 KUHPerdata berbunyi :

"jika suatu pekerjaan dikerjakan sepotong demi sepotong atau seukuran demi seukuran, maka pekerjaan dapat diperiksa sebagian demi sebagian ....dst".

Dari keadaan di atas dapat disimpulkan bahwa hubungan hukum yang terjadi antara perusahaan asuransi kerugian dengan perusahaan loss adjuster merupakan perjanjian untuk melakukan pekerjaan, yang memenuhi ketentuan dalam Bab Ketujuh Bagian Kesatu dan Bagian Keenam, Pasal 1601, 1601b, 1604 dan Pasal 1608 KUHPerdata.

Apabila diperhatikan lebih jauh, perjanjian antara loss adjuster dengan perusahaan asuransi yang menunjuknya berpegang teguh pada suatu asas yang terdapat dalam suatu perjanjian, yaitu "asas kepercayaan"(vertrouwensbeginsel).

Dalam hukum asuransi "asas kepercayaan" sama dengan "asas kejujuran yang sempurna". Untuk istilah kejujuran yang sempurna, dalam perjanjian asuransi yang lazimnya dipakai adalah "asas itikad baik" (principle of utmost godd faith atau ubberrimefidei). Pada prinsipnya asas kejujuran ini merupakan asas yang harus ada dan dipenuhi oleh para pihak dalam setiap perjanjian, karena asas dasar yang harus dimiliki oleh setiap orang yang ingin mengadakan perjanjian, bahkan dalam perjanjian asuransi atau pertanggungan, unsur "utmost 
good faith" atau byzondere vertrouwens karakter" memegang peranan penting. ${ }^{12}$ Tidak dipenuhinya asas ini pada saat akan menutup suatu perjanjian akan menyebabkan adanya cacat kehendak, sebagaimana makna dari seluruh ketentuan - ketentuan dasar yang diatur oleh Pasal 1320-1329 KUHPerdata. ${ }^{13}$ Bagaimanapun juga itikad baik merupakan suatu dasar utama dalam kepercayaan yang melandasi suatu perjanjian. Seseorang yang mengadakan perjanjian dengan pihak lain menumbuhkan kepercayaan di antara kedua belah pihak, dan satu sama lain akan memegang janjinya dan akan memenuhi prestasinya di kemudian hari. Tanpa adanya kepercayaan di antara para pihak tidak mungkin akan diadakan perjanjian tersebut dengan kepercayaan ini mereka mau mengikatkan dirinya. Dengan demikian bagi keduanya, perjanjian itu mempunyai kekuatan mengikat sebagai undang-undang. ${ }^{14}$

Demikian juga halnya dengan perjanjian antara pihak perusahan asuransi kerugian dengan perusahaan loss adjuster, perjanjian awal mereka yang di dahului dengan perjanjian secara lisan yang dilakukan dengan didasari oleh suatu itikad baik dan adanya kepercayaan di antara mereka.

Selanjutnya mengingat perusahaan loss adjuster merupakan rekanan / mitra kerja perusahaan asuransi kerugian, maka tugas yang diberikan oleh perusahaan asuransi kerugian pada perusahaan loss adjuster yang dituangkan dalam surat perjanjian atau surat perintah kerja, dilaksanakan oleh loss adjuster untuk kepentingan perusahaan asuransi kerugian. Dengan demikian hubungan hukum yang terjadi juga merupakan pemberian kuasa yang memenuhi ketentuan Pasal 1792 KUHPerdata, karena dalam perjanjian pemberian kuasa menimbulkan hubungan yang bersifat sama tinggi atau sama derajat, karena mereka adalah rekanan / mitra, dan dalam hal ini berbeda dengan perjanjian perburuhan yang diatur dalam Pasal 1601a, yang menimbulkan hubungan sub ordinasi antara atasan dan bawahan meskipun sama - sama mengenai melakukan pekerjaan.

\footnotetext{
${ }^{12}$ Emmy Pangaribuan Simandjuntak, Hukum Pertanggungan dan Perkembangannya, (Jakarta : BPHN, 1983), hal. 36

${ }^{13}$ Sri Redjeki Hartono, Hukum Asuransi dan Perusahaan Asuransi, (Jakarta : Sinar Grafika, 1992), hal 103

${ }^{14}$ Mariam Darus B, Buku II, Hukum Perikatan dengan Penjelasan, (Bandung, Alumni, 1983), hal 113
} 
Perjanjian pemberian kuasa diatur dalam Bab XI C Buku III KUHPerdata mulai dari Pasal 1792 sampai dengan Pasal 1819.

Menurut Pasal 1729 KUHPerdata :

"pemberian kuasa adalah suatu perjanjian dengan mana seseorang memberi kuasa kepada orang lain yang menerimanya untuk dan atas nama pemberi kuasa untuk menyelenggarakan suatu urusan”.

Selanjutnya Pasal 1794 KUHPerdata menyebutkan :

"pemberian kuasa terjadi dengan cuma - cuma kecuali jika diperjanjikan sebaliknya".

Dalam konteksnya dengan kedua pasal di atas, maka loss adjuster melakukan tugas penilaiannya atas nama perusahaan asuransi kerugian yang telah menunjuknya, yang tertuang dalam surat penunjukkan atau surat perintah kerja, dan untuk kepentingan perusahaan asuransi kerugian dengan konsekwensi mendapat upah dari perusahaan asuransi kerugian sesuai dengan yang diperjanjikan. Jadi dapat disimpulkan bahwa perusahaan asuransi kerugian sebagai yang memberi kuasa dan perusahaan loss adjuster sebagai yang diberi kuasa untuk menyelenggarakan suatu urusan dalam hal mengadakan penilaian kerugian di lapangan dan untuk atas nama kepentingan perusahaan asuransi kerugian, walaupun tidak ditulis dengan tegas di dalam surat penunjukkan atau surat perintah kerja tersebut. Perjanjian pemberian kuasa oleh undang-undang lazimnya terjadi sebagai suatu jasa seseorang terhadap temannya, yang karena itu dianggap pada umumnya tidak mendapatkan upah, kecuali jika diperjanjikan upah tertentu, maka upah tersebut harus dibayar sesuai dengan kesepakatan atau sesuai dengan kebiasaan. ${ }^{15}$

Dengan demikian dari isi surat penunjukkan atau surat perintah kerja dan pedoman kerja loss adjuster, selanjutnya dengan mengingat bahwa perusahaan asuransi kerugian dengan perusahaan loss adjuster merupakan rekanan/mitra kerja, maka dapat disimpulkan bahwa antara perusahaan asuransi kerugian dengan perusahaan loss adjuster telah terjadi hubungan hukum yang termasuk dalam perjanjian campuran berupa "perjanjian pemborongan pekerjaan dan

\footnotetext{
${ }^{15} \mathrm{HMN}$ Purwosucipto, Op cit, hal 147
} 
perjanjian pemberian kuasa yang memenuhi ketentuan Buku Ketiga, Bab Ketujuh KUHPerdata tentang "Persetujuan-persetujuan untuk melakukan pekerjaan" pada bagian Kesatu dan bagian Keenam, yaitu Pasal 1601, 1601b, 1604, 1608 dan Bab Keenambelas tentang "perjanjian pemberian kuasa” yaitu Pasal 1792.

\section{Penutup}

Setelah memperlihatkan isi surat penunjukkan atau surat perintah kerja, dapat disimpulkan perjanjian yang terjadi antara loss adjuster asuransi dengan perusahaan asuransi kerugian adalah perjanjian campuran yaitu perjanjian pemborongan pekerjaan dan perjanjian pemberian kuasa, yang diatur dalam KUHPerdata Buku Ketiga Bab Ketujuh tentang "Persetujuan - persetujuan untuk melakukan pekerjaan" pada Pasal 1601, 1601b, 1604, 1608, dan Pasal 1792 tentang "Perjanjian Pemberian Kuasa". Perusahaan adjuster asuransi merupakan rekanan atau mitra kerja dari perusahaan asuransi kerugian., di mana loss adjuster dalam melakukan pekerjaanya mendapat upah / fee dari perusahaan asuransi kerugian.

Selanjutnya perjanjian antara perusahaan loss adjuster yang telah menunjuknya berpegang teguh pada asas kepercayaan (vertrouwnsbeginsel). Dalam hukum asuransi sama dengan asas kejujuran yang sempurna atau asas iktikad baik.

\section{DAFTAR PUSTAKA}

Badrulzaman, Mariam Darius, KUHPerdata Buku II, Hukum Perikatan dengan Penjelasan, Alumni, Bandung, 1983

Burkinstravo, MJ., Study Course Introduction Insurance, Institute of New Zeland, 1996

Darmawi, Herman, Manajemen Asuransi, Bumi Aksara, Jakarta, 2000

Dewan Asuransi Indonesia, Panduan Memilih Asuransi Kerugian, KIat mengatasi Kerugian, Kompas Gramedia, Jakarta, 2000

Emmy Pangaribuan Simandjuntak, Hukum Pertanggungan dan

Perkembangannya, Jakarta, BPHN, 1983. 
Hartono, Sri Rejeki, Hukum Asuransi dan Perusahaan Asuransi, Sinar Grafika, Jakarta, 1992,

Kartini Mulyadi dan Gunawan Wijaya, Perikatan Pada Umumnya, Jakarta: Raja Grafindo, 2004

Loebis AB, Adjuster (Pemeriksaan Klaim Asuransi),Jakarta: Dewan Asuransi Indonesia, 1964.

Miru, Ahmadi, Hukum Kontrak, Perancangan Kontrak, Rajawali Press, Jakarta, 2007

Purwosucipto, HMN., Pengertian Pokok-Pokok Hukum Dagang Indonesia, Hukum Pertanggungan, Alumni, Bandung, 1996

Raharjo, Handri, Hukum Perjanjian di Indonesia, Pustaka Yustisia, Yogyakarta, 2009

Republik Indonesia, Undang - Undang N0.2 tahun 1992 tentang Usaha Perasuransian.

Republik Indonesia, Undang - Undang N0.2 tahun 1992 tentang Usaha Perasuransian.

Subekti R dan Tjitrosudibyo, Kitab Undang - Undang Hukum Dagang dan Undang-Undang Kepailitan, Pradnya Paramita, Jakarta, 1983. 